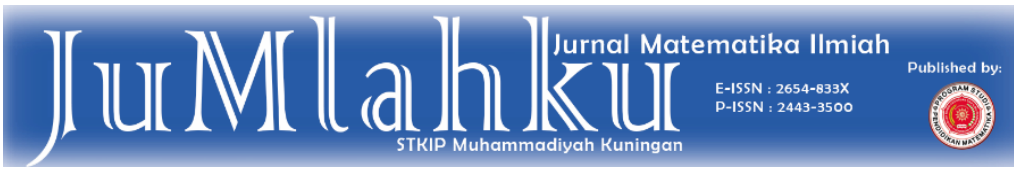

Submited: 20-11-2021

Published: 15-12-2021

\title{
Media Hippo Animator pada Pembelajaran Statistika dalam Upaya Meningkatkan Kemampuan Statistik dan Self-confidence Mahasiswa di Era Pandemi Covid 19
}

Abas Hidayat $^{\text {a) }}$, Fani Juliyanto Perdana ${ }^{a)}$

a) Sekolah Tinggi Ilmu Kesehatan Cirebon, abasstikescirebon@gmail.com

\begin{tabular}{|c|c|}
\hline Article Info & Abstract \\
\hline $\begin{array}{l}\text { Kaywords : hippo Animator; } \\
\text { statistical ability; self- } \\
\text { confidence }\end{array}$ & $\begin{array}{l}\text { In the Covid-19 Pandemic Era, there has been a change in the } \\
\text { learning process. The learning process becomes unlimited by space } \\
\text { and time. The use of ICT is a challenge and motivation for teachers } \\
\text { to be able to innovate in teaching styles or methods. Hippo Animator } \\
\text { has flexibility for students to be used both online and offline. The } \\
\text { purpose of this research is to analyze the use of Hippo animator to } \\
\text { optimize online learning outcomes in the COVID-19 pandemic era. } \\
\text { This research used a quantitative approach through a quasi- } \\
\text { experimental design. The subject of this research is } 164 \text { students. } 2 \\
\text { classes are control class with } 82 \text { students. } 2 \text { classes are experimental } \\
\text { class with } 82 \text { students. The result of this research is that the use of } \\
\text { Hippo Animation can significantly increase statistical ability and self- } \\
\text { confidence. In addition, it can significantly improve statistical literacy, } \\
\text { statistical reasoning and statistical thinking. The application of Hippo } \\
\text { Aminator in statistics learning can provide a different learning } \\
\text { atmosphere }\end{array}$ \\
\hline
\end{tabular}


Kata Kunci:

hippo Animator;

kemampuan statistik; selfconfidence

\section{Abstrak}

Di Era Pandemi Covid 19 perubahan terjadi yaitu pada proses pembelajaran. Proses pembelajaran menjadi tidak dibatasi oleh ruang dan waktu. Penggunaan ICT merupakan sebuah tantangan dan salah satu bentuk motivasi bagi pengajar untuk dapat berinovasi dalam gaya atau metode mengajar. Hippo Animator memiliki fleksibelitas bagi peserta didik dapat digunakan secara online dan offline. Tujuan Penelitian ini yaitu menganalsis penggunaan Hippo animator dalam upaya mengoptimalkan hasil belajar secara daring di era pandemi covic 19. Penelitian ini menggunakan pendekatan kuantitatif melalui desain kuasi-eksperimen. Subjek penelitian ini adalah 164 mahasiswa. 2 kelas adalah kelas kontrol sebanyak 82 mahasiswa. 2 kelas adalah kelas eksperimen sebanyak 82 mahasiswa. Hasil penelitian ini adalah penggunaa Hippo Animasi dapat meningkatkan kemampuan statistika dan self-confidence secara signifikan. Selain itu, dapat meningkatkan kemampuan melek statistik (statistical literacy), penalaran statistik (statistical reasoning) dan berfikir statistik (statistical thinking) secara signifikan. Penerapan Hippo Aminator pada penelitian ini memberikan warna berbeda dalam pembelajaran statistika. 


\section{PENDAHULUAN}

Perkembangan penyebaran covid 19 sangat cepat dan luas, baik di Indonesia maupun luar negeri. Berdampak terhadap bidang ekonomi dan pendidikan (Dennis, 2020). Di Bidang pendidikan sebagai akibat dari pandemi global yang disebabkan oleh COVID-19, perubahan terjadi pada proses pembelajaran. Pendidik dan peserta dituntut beradaptasi dengan teknologi dikarenakan oleh perubahan sistem pembejaran menjadi digital (Torres Martín et al., 2021). Supaya hasil pembelajaran dapat tercapai secara maksimal maka diperlukan pengembangan-pengembangan media pembelajaran. (Maskur et al., 2017) mengembangkan Macromedia Flash pada pembelajaran matematika. (Rahmat et al., 2019) mengembangkan mobile learning sebagai media pembelajaran. (Amanullah, 2020) mengembangkan Flipbook Digital untuk menunjang proses pembelajaran. Terdapat banyak penelitian yang membahas terkait media pembelajaran digital.

Pemanfaatan terknologi termasuk di dalamnya adalah pemanfaatan dalam bidang pendidikan, sehingga dapat memaksimalkan proses belajar mengajar melalui teknologi. Perkembangan teknologi yang pesat saat ini, merupakan alasan utama penggunaan ICT sebagai media pembelajaran. Dengan menggunakan ICT, maka proses pembelajaran menjadi tidak terbatas oleh ruang dan waktu, Penggunaan ICT inilah merupakan sebuah tantangan bagi pengajar dan salah satu bentuk motivasi bagi pengajar untuk dapat berinovasi dalam gaya atau metode mengajar. (Umbara et al., 2020) mengatakan bahwa salah satu software berbasis ICT yang dapat digunakan untuk mengembangkan media pembelajaran adalah Hippo Animator.

Prinsip media pembelajaran yaitu dapat mempermudah dalam pemberian dan penerimaan materi (Kurniawati \& Koeswanti, 2021). Hal tersebut bermakna media haruslah mudah digunakan oleh pendidik dan peserta. Prinsip inilah yang digunakan sebagai landasan pemilihan media pada penelitian ini. Salah satu media yang efektif, efisien, menarik, interaktif dan mudah digunakan adalah media berbasis html yaitu Hippo Animator (Umbara et al., 2020). Alasan memilih Hippo Animator adalah memiliki fleksibelitas bagi peserta didik dapat digunakan secara online dan offline (Puadi, 2020).

Upaya untuk mengembangkan dan menciptakan nilai dari hasil pendidikan, diperlukan suatu upaya 
memperdalam tentang bagaimana orang belajar statistika. Kalangan masyarakarakat baik pelajar, para ilmuwan, para profesi, dan lain-lain diharapkan dapat mengaplikasikan pemikiran statistik untuk meningkatkan hasil pekerjaan mereka. Dalam belajar statistik kemampuan yang dikembangkan adalah melek statistik (statistical literacy), statistik (statistical reasoning) dan berpikir statistik (statistical thinking) (Martadiputra, 2010).

Statistika sebagai salah satu bagian dari bidang matematika, mempunyai peran yang penting terhadap keberhasilan belajar mahasiswa yang ditandai dengan kesuksesan mahasiswa dalam menulis karya tulis yaitu baik skripsi, tesis maupun disertasi. Statistika digunakan dalam skripsi baik secara deskriptif maupun inferensial. $\mathrm{Di}$ perguruan tinggi Indonesia diketahui statistika merupakan mata kuliah yang menakutkan bagi para mahasiswa (Ulpah, 2009). Tidak sedikit mahasiswa kurang menyukai matakuliah statistik dan dianggap sebagai mata kuliah yang sulit. Hal tersebut mengakibatkan kecemasan mahasiswa meningkat terutama mahasiswa non matematika (Nazliati et al., 2019)]. Sebagian beranggapan kesulitan terjadi akibat faktor non- kognitif seperti sikap, persepsi, minat, harapan dan motivasi (Sahari et al., 2011).

Faktor afektif berdampak pada capaian pembelajaran (Hidayat \& Perdana, 2019). Sikap dan persepsi mahasiswa terhadap mata kuliah statistika memerlukan perhatian yang substansial karena berdampak pada proses belajar mengajar. Ketika kuliah statistika perasaan negatif dibawa oleh para mahasiswa, mahasiswa dapat menikmati kuliah, merespon dengan baik, asalkan dosennya antusias (Hollis, 2011). Membangun sikap antusias mahasiswa dapat dilakukan melalui penggunaan media pembelajaran yang interaktif.

Self-confidence merupakan salah satu faktor psikologis yang sangat penting untuk mengembangkan kemampuan peserta didik yang merupakan subjek dari beberapa penelitian tentang prestasi peserta didik (Hosein \& Harle, 2018; Waini et al., 2014). Self-confidence kemampuan setiap orang untuk meningkatkan motivasi dan merupakan aset berharga bagi individu tersebut. Salah satu kunci penting sukses adalah self-confidence (Budin, 2017). Self-confidence dapat merujuk pada berbagai keyakinan seseorang tentang kemampuan dan kapabilitas mereka, yang sudah 
ditetapkan dan diukur secara formal dengan cara yang berbeda. Selfconfidence memberikan manfaat dalam praktek pendidikan dan memotivasi peserta didik (Sheldrake, 2016). Terbentuknya self-confidence disebabkan adanya faktor internal seperti konsep diri, kondisi fisik, harga diri dan pengalaman hidup. Terbentuknya self-confidence dipengaruhi oleh faktor eksternal yaitu pendidikan, pekerjaan dan lingkungan (Ghufron \& Risnawita, 2011).

Pada era pademi covid 19 ini, dibutuhkan pengembangan mediamedia pembelajaran secara online, dengan tujuan memaksimalkan hasil belajar siswa. Seperti kita ketahui bahwa para pembelajar saat ini sangat dekat dengan teknologi. Peneilitian ini menerapkan media hippo animator pada pembelajaran statistika, dalam upaya meningkatkan kemampuan statistika peserta didik di era pandemic covid 19. Selain itu, memperhatikan faktor internal dalam mencapai tujuan pendidikan, penelitian ini juga menganalisis peningkatan faktor psikologi yaitu self-confidence. Tujuan Penelitian ini yaitu mengembangkan Hippo animator sebagai pembeda dengan penelitian di atas dan dalam upaya mengoptimalkan hasil belajaran secara daring di era pandemi covic 19, kemudian menganalisis pengaruhnya terhadap self-confedence sebagai satu faktor afektif peserta didik untuk mencapai tujuan pembelajaran.

\section{METODE}

Penelitian ini menggunakan pendekatan kuantitatif melalui desain kuasi-eksperimen yang menggunakan kelompok eksperimen dan kontrol. Tempat penelitian, fakultas syari'ah, IAIN Syekh Nurjati Cirebon, Jl. Perjuangan Cirebon. Pemilihan tempat penelitian berdasarkan pertimbangan jumlah bahwa mahasiwa yang banyak dan mempunyai karakteristik individu yang tidak jauh berbeda yaitu jurusan dan semester yang sama.

Subjek penelitian ini adalah 164 mahasiswa, jurusan $S 1$ Hukum Ekonomi Syari'ah, sebanyak 4 kelas. Dengan rincian, 2 kelas adalah kelas kontrol sebanyak 82 mahasiswa. 2 kelas adalah kelas eksperimen sebanyak 82 mahasiswa.

Kelas eksperimen menggunakan pembelajaran dilakukan secara daring menggunakan zoom \& Hippo animator pada mata kuliah statistik. Kelas control Kelas eksperimen menggunakan pembelajaran dilakukan secara daring menggunakan zoom dan google meet. Hipotesis 1 
H0: Tidak ada perbedaan yang signifikan peningkatan kemampuan statistik kelas kontrol dan eksperimen yang melakukan pembelajaran menggunakan hippo animasi di era pandemi covid 19

$\mathrm{H} 1$ : Ada perbedaan yang signifikan peningkatan kemampuan statistik kelas kontrol dan eksperimen yang melakukan

pembelajaran menggunakan hippo animasi di era pandemi covid 19

Hipotesis 2

H0: Tidak ada perbedaan yang signifikan peningkatan kemampuan melek statistik (statistical literacy) kelas kontrol dan eksperimen yang melakukan

pembelajaran menggunakan hippo animasi di era pandemi covid 19

$\mathrm{H1}$ : Ada perbedaan yang signifikan peningkatan kemampuan melek statistik (statistical literacy) kelas kontrol dan eksperimen yang melakukan pembelajaran menggunakan hippo animasi di era pandemi covid 19

Hipotesis 3

H0: Tidak ada perbedaan yang signifikan peningkatan kemampuan penalaran statistik (statistical reasoning) kelas kontrol dan eksperimen yang melakukan pembelajaran menggunakan hippo animasi di era pandemi covid 19

$\mathrm{H} 1$ : Ada perbedaan yang signifikan peningkatan kemampuan penaran statistik (statistical reasoning) kelas kontrol dan eksperimen yang melakukan pembelajaran menggunakan hippo animasi di era pandemi covid 19

Hipotesis 4

H0: Tidak ada perbedaan yang signifikan peningkatan kemampuan berfikir statistik (statistical thinking) kelas kontrol dan eksperimen yang melakukan pembelajaran menggunakan hippo animasi di era pandemi covid 19

$\mathrm{H} 1$ : Ada perbedaan yang signifikan peningkatan kemampuan berfikir statistik (statistical thinking) kelas kontrol dan kelas eksperimen yang melakukan

pembelajaran menggunakan hippo animasi di era pandemi covid 19

\section{Hipotesis 5}

H0: Tidak ada peningkatan yang signifikan self-confidence kelas kontrol yang melakukan pembelajaran online tanpa menggunakan hippo animasi di era pandemi covid 19

$\mathrm{H} 1$ : Ada peningkatan yang signifikan self-confidence kelas kontrol yang melakukan pembelajaran online tanpa menggunakan hippo animasi di era pandemi covid 19 
Hipotesis 6

$\mathrm{HO}$ : Tidak ada peningkatan yang signifikan self-confidence kelas eksperimen yang melakukan pembelajaran menggunakan hippo animasi di era pandemi covid 19

$\mathrm{H} 1$ : Ada peningkatan yang signifikan self-confidence kelas eksperimen yang melakukan pembelajaran menggunakan hippo animasi di era pandemi covid 19

Analisis data peningkatan kemampuan statistik menggunakan data nilai N-Gain. Analisis data peningkatan self-confidence menggunakan data hasil angket. Uji asumsi statistik pada data N-Gain menggunakan uji normalitas dan homogenitas. Uji hipotesis menggunakan uji non parametrik yaitu uji Mann Whitney U.

\section{HASIL}

\section{Deskripsi Kemampuan Statistik}

\subsection{Kemampuan Statistik Kelas} Kontrol

Klasifikasi kemampuan dimodifikasi dari penelitian (Setiawan et al., 2017). Tabel 1 dan Grafik 1 berikut ini adalah klasifikasi kemampuan statistik setiap mahasiswa.
Tabel 1. Klasifikasi Kemampuan

Statistik Kelas Kontrol

\begin{tabular}{|c|c|c|c|c|}
\hline Klasifi & \multicolumn{2}{|c|}{ Sebelum } & \multicolumn{2}{c|}{ Sesudah } \\
\cline { 2 - 5 } $\begin{array}{c}\text { kemi } \\
\text { Kema } \\
\text { mpua } \\
\mathbf{n} \\
\text { Statist } \\
\text { ik }\end{array}$ & $\begin{array}{c}\text { Frek } \\
\text { uens } \\
\mathbf{i}\end{array}$ & $\begin{array}{c}\text { Prese } \\
\text { ntase }\end{array}$ & $\begin{array}{c}\text { Frek } \\
\text { uens } \\
\mathbf{i}\end{array}$ & $\begin{array}{c}\text { Prese } \\
\text { ntase }\end{array}$ \\
\hline Tinggi & 5 & 6,10 & 25 & 30,49 \\
\hline $\begin{array}{c}\text { Sedan } \\
\text { g }\end{array}$ & 20 & 24,39 & 44 & 53,66 \\
\hline $\begin{array}{c}\text { Renda } \\
\text { h }\end{array}$ & 57 & 69,51 & 13 & 15,85 \\
\hline
\end{tabular}

\section{Kemampuan Statistik Kelas Kontrol}

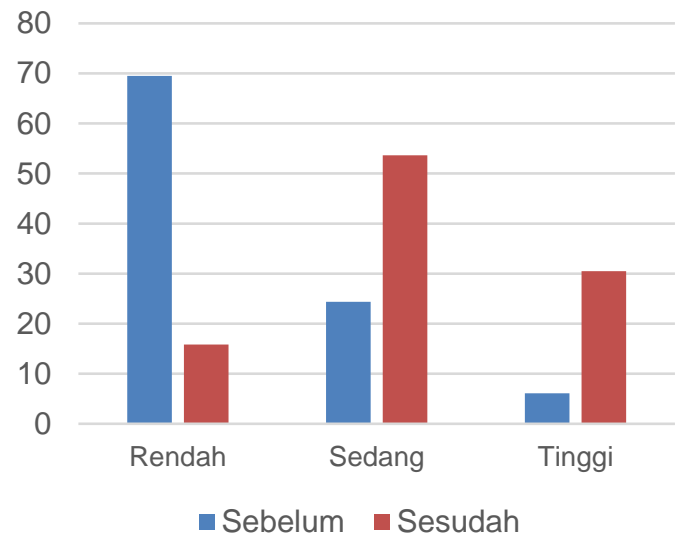

Grafik 1. Klasifikasi Kemampuan Statistik Kelas Kontrol

Tabel 1 dan Grafik 1 di atas menggambarkan persentase jumlah mahasiswa yang mempunyai kemampuan statistika sebelum dan sesudah pembelajaran pada kelas 
kontrol. Pada kelas kontrol persentase jumlah mahasiswa yang mempunyai kemampuan statistik rendah mengalami penurunan setelah dilakukan pembelajaran. Persentase jumlah mahasiswa yang mempunyai kemampuan statistik sedang mengalami kenaikan setelah dilakukan pembelajaran. Persentase jumlah mahasiswa yang mempunyai kemampuan statistik tinggi mengalami kenaikan setelah dilakukan pembelajaran.

Berikut ini adalah tabel rincian klasifikasis kemampuan statistik setiap mahasiswa pada setiap indikator yaitu melek statistik (statistical literacy), penalaran statistik (statistical reasoning) dan berpikir statistik (statistical thinking) pada kelas kontrol sebelum dan sesudah pembelajaran.

Tabel 2. Klasifikasi Kemampuan pada Indikator Kemampuan Statistik

\begin{tabular}{|c|c|c|c|c|c|}
\hline \multirow[b]{2}{*}{$\begin{array}{c}\text { Indi } \\
\text { kato } \\
\text { r } \\
\text { kem } \\
\text { amp } \\
\text { uan } \\
\text { stati } \\
\text { stik }\end{array}$} & \multirow[b]{2}{*}{$\begin{array}{c}\text { Klasi } \\
\text { fikas } \\
\text { i } \\
\text { Kem } \\
\text { amp } \\
\text { uan }\end{array}$} & \multicolumn{2}{|c|}{ Sebelum } & \multicolumn{2}{|c|}{ Sesudah } \\
\hline & & $\begin{array}{c}\text { Fre } \\
\text { kue } \\
\text { nsi }\end{array}$ & $\begin{array}{c}\text { Pre } \\
\text { sent } \\
\text { ase }\end{array}$ & $\begin{array}{c}\text { Fre } \\
\text { kue } \\
\text { nsi }\end{array}$ & $\begin{array}{c}\text { Pre } \\
\text { sent } \\
\text { ase }\end{array}$ \\
\hline \multirow{3}{*}{$\begin{array}{l}\text { Mele } \\
\mathrm{k} \\
\text { stati } \\
\text { stik } \\
\text { (stati } \\
\text { stical }\end{array}$} & $\begin{array}{c}\text { Ting } \\
\text { gi }\end{array}$ & 5 & 6,10 & 36 & $\begin{array}{c}43,9 \\
0\end{array}$ \\
\hline & $\begin{array}{c}\text { Seda } \\
\text { ng }\end{array}$ & 27 & $\begin{array}{c}32,9 \\
3\end{array}$ & 38 & $\begin{array}{c}46,3 \\
4\end{array}$ \\
\hline & $\begin{array}{c}\text { Rend } \\
\text { ah }\end{array}$ & 50 & $\begin{array}{c}60,9 \\
8\end{array}$ & 8 & 9,76 \\
\hline
\end{tabular}

\begin{tabular}{|c|c|c|c|c|c|}
\hline \multicolumn{6}{|l|}{$\begin{array}{c}\text { litera } \\
\text { cy) }\end{array}$} \\
\hline \multirow{3}{*}{$\begin{array}{c}\text { Pen } \\
\text { alara } \\
n \\
\text { stati } \\
\text { stik } \\
\text { (stati } \\
\text { stical } \\
\text { reas } \\
\text { onin } \\
\text { g) }\end{array}$} & $\begin{array}{c}\text { Ting } \\
\text { gi }\end{array}$ & 5 & 6,10 & 25 & $\begin{array}{c}30,4 \\
9\end{array}$ \\
\hline & $\begin{array}{c}\text { Seda } \\
\text { ng }\end{array}$ & 20 & $\begin{array}{c}24,3 \\
9\end{array}$ & 43 & $\begin{array}{c}52,4 \\
4\end{array}$ \\
\hline & $\begin{array}{l}\text { Rend } \\
\text { ah }\end{array}$ & 57 & $\begin{array}{c}69,5 \\
1\end{array}$ & 14 & $\begin{array}{c}17,0 \\
7\end{array}$ \\
\hline \multirow{3}{*}{$\begin{array}{l}\text { Berp } \\
\text { ikir } \\
\text { stati } \\
\text { stik } \\
\text { (stati } \\
\text { stical } \\
\text { think } \\
\text { ing) }\end{array}$} & $\begin{array}{c}\text { Ting } \\
\text { gi }\end{array}$ & 5 & 6,10 & 23 & $\begin{array}{c}28,0 \\
5 \\
\end{array}$ \\
\hline & $\begin{array}{c}\text { Seda } \\
\text { ng }\end{array}$ & 16 & $\begin{array}{c}19,5 \\
1\end{array}$ & 44 & $\begin{array}{c}53,6 \\
6\end{array}$ \\
\hline & $\begin{array}{l}\text { Rend } \\
\text { ah }\end{array}$ & 61 & $\begin{array}{c}74,3 \\
9\end{array}$ & 15 & $\begin{array}{c}18,2 \\
9\end{array}$ \\
\hline
\end{tabular}

Tabel 2 di atas menggambarkan persentase jumlah mahasiswa yang mempunyai kemampuan melek statistik (statistical literacy) sebelum dan sesudah pembelajaran pada kelas kontrol. Pada kelas kontrol persentase jumlah mahasiswa yang mempunyai kemampuan melek statistik (statistical literacy) rendah mengalami penurunan setelah dilakukan pembelajaran. Persentase jumlah mahasiswa yang mempunyai kemampuan melek statistik (statistical literacy) sedang mengalami kenaikan setelah dilakukan pembelajaran. Persentase jumlah mahasiswa yang mempunyai kemampuan melek statistik (statistical literacy) tinggi mengalami kenaikan setelah dilakukan pembelajaran. 
Tabel 2 di atas menggambarkan persentase jumlah mahasiswa yang mempunyai kemampuan penalaran statistik (statistical reasoning) sebelum dan sesudah pembelajaran pada kelas kontrol. Pada kelas kontrol persentase jumlah mahasiswa yang mempunyai kemampuan penalaran statistik (statistical reasoning) rendah mengalami penurunan setelah dilakukan pembelajaran. Persentase jumlah mahasiswa yang mempunyai kemampuan penalaran statistik (statistical reasoning) sedang mengalami kenaikan setelah dilakukan pembelajaran. Persentase jumlah mahasiswa yang mempunyai kemampuan penalaran statistik (statistical reasoning) tinggi mengalami kenaikan setelah dilakukan pembelajaran.

Tabel 2 di atas menggambarkan persentase jumlah mahasiswa yang mempunyai kemampuan berpikir statistik (statistical thinking) sebelum dan sesudah pembelajaran pada kelas kontrol. Pada kelas kontrol persentase jumlah mahasiswa yang mempunyai kemampuan berpikir statistik (statistical thinking) rendah mengalami penurunan setelah dilakukan pembelajaran. Persentase jumlah mahasiswa yang mempunyai kemampuan berpikir statistik (statistical thinking) sedang mengalami kenaikan setelah dilakukan pembelajaran. Persentase jumlah mahasiswa yang mempunyai kemampuan berpikir statistik (statistical thinking) tinggi mengalami kenaikan setelah dilakukan pembelajaran.

\subsection{Kemampuan Statistik Kelas Eksperimen}

Berikut ini adalah tabel dan grafik klasifikasi kemampuan statistik setiap mahasiswa pada kelas ekperimen sebelum dan sesudah pembelajaran.

Tabel 3. Klasifikasi Kemampuan

Statistik Kelas Eksperimen

\begin{tabular}{|c|c|c|c|c|}
\hline $\begin{array}{c}\text { Klasifi } \\
\text { kasi } \\
\text { Kema } \\
\text { mpua } \\
\mathbf{n} \\
\text { Statist } \\
\text { ik }\end{array}$ & $\begin{array}{c}|c| \\
\text { uens } \\
\mathbf{i}\end{array}$ & $\begin{array}{c}\text { Sebelum } \\
\text { ntase }\end{array}$ & $\begin{array}{c}\text { Prek } \\
\text { uens } \\
\mathbf{i}\end{array}$ & $\begin{array}{c}\text { Prese } \\
\text { ntase }\end{array}$ \\
\hline Tinggi & 0 & 0,00 & 66 & 80,49 \\
\hline $\begin{array}{c}\text { Sedan } \\
\text { g }\end{array}$ & 9 & 10,98 & 16 & 19,51 \\
\hline $\begin{array}{c}\text { Renda } \\
\text { h }\end{array}$ & 73 & 89,02 & 0 & 0,00 \\
\hline \multicolumn{2}{|c|}{}
\end{tabular}




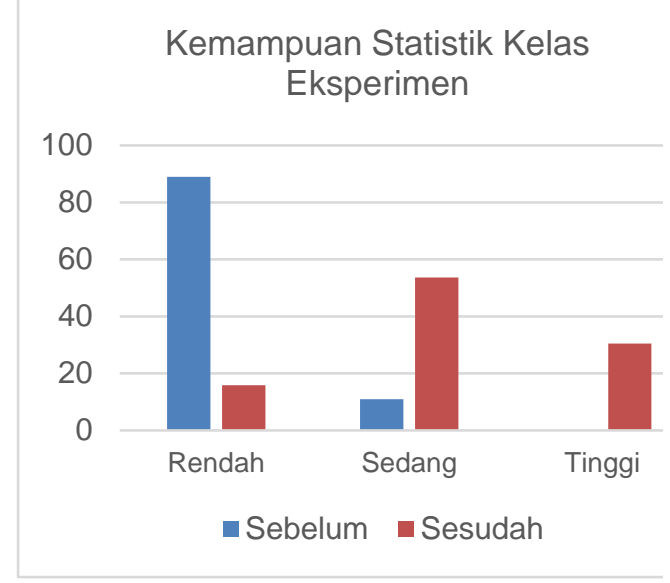

Grafik 2. Klasifikasi Kemampuan Statistik Kelas Eksperimen

Tabel 3 dan Grafik 2 di atas menggambarkan persentase jumlah mahasiswa yang mempunyai kemampuan statistik sebelum dan sesudah pembelajaran pada kelas eksperimen. Pada kelas eksperimen persentase jumlah mahasiswa yang mempunyai kemampuan statistik rendah mengalami penurunan setelah dilakukan pembelajaran. Persentase jumlah mahasiswa yang mempunyai kemampuan statistika sedang mengalami kenaikan setelah dilakukan pembelajaran. Persentase jumlah mahasiswa yang mempunyai kemampuan statistik tinggi mengalami kenaikan setelah dilakukan pembelajaran.
Berikut ini adalah tabel rincian klasifikasi kemampuan statistik setiap mahasiswa pada setiap indikator yaitu melek statistik (statistical literacy), penalaran statistik (statistical reasoning) dan berpikir statistik (statistical thinking) pada kelas kontrol sebelum dan sesudah pembelajaran.

Tabel 4. Klasifikasi Kemampuan pada Indikator Kemampuan Statistik

\begin{tabular}{|c|c|c|c|c|c|}
\hline \multirow{2}{*}{$\begin{array}{c}\text { Indi } \\
\text { kato } \\
\text { r } \\
\text { kem } \\
\text { amp } \\
\text { uan } \\
\text { stati } \\
\text { stik }\end{array}$} & \multirow[b]{2}{*}{$\begin{array}{c}\text { Klasi } \\
\text { fikas } \\
i \\
\text { Kem } \\
\text { amp } \\
\text { uan }\end{array}$} & \multicolumn{2}{|c|}{ Sebelum } & \multicolumn{2}{|c|}{ Sesudah } \\
\hline & & $\begin{array}{l}\text { Fre } \\
\text { kue } \\
\text { nsi }\end{array}$ & $\begin{array}{l}\text { Pre } \\
\text { sent } \\
\text { ase }\end{array}$ & $\begin{array}{l}\text { Fre } \\
\text { kue } \\
\text { nsi }\end{array}$ & $\begin{array}{l}\text { Pre } \\
\text { sent } \\
\text { ase }\end{array}$ \\
\hline \multirow{3}{*}{$\begin{array}{c}\text { Mele } \\
\mathrm{k} \\
\text { stati } \\
\text { stik } \\
\text { (stati } \\
\text { stical } \\
\text { litera } \\
\text { cy) }\end{array}$} & $\begin{array}{c}\text { Ting } \\
\text { gi } \\
\end{array}$ & 0 & 0,00 & 65 & $\begin{array}{c}79,2 \\
7 \\
\end{array}$ \\
\hline & $\begin{array}{c}\text { Seda } \\
\text { ng }\end{array}$ & 13 & $\begin{array}{c}15,8 \\
5 \\
\end{array}$ & 17 & $\begin{array}{c}20,7 \\
3\end{array}$ \\
\hline & $\begin{array}{c}\text { Rend } \\
\text { ah }\end{array}$ & 69 & $\begin{array}{c}84,1 \\
5\end{array}$ & 0 & 0,00 \\
\hline \multirow{3}{*}{$\begin{array}{c}\text { Pen } \\
\text { alara } \\
\mathrm{n} \\
\text { stati } \\
\text { stik } \\
\text { (stati } \\
\text { stical } \\
\text { reas } \\
\text { onin } \\
\text { g) }\end{array}$} & $\begin{array}{c}\text { Ting } \\
\text { gi }\end{array}$ & 0 & 0,00 & 59 & $\begin{array}{c}71,9 \\
5 \\
\end{array}$ \\
\hline & $\begin{array}{c}\text { Seda } \\
\text { ng }\end{array}$ & 9 & $\begin{array}{c}10,9 \\
8 \\
\end{array}$ & 23 & $\begin{array}{c}28,0 \\
5 \\
\end{array}$ \\
\hline & $\begin{array}{l}\text { Rend } \\
\text { ah }\end{array}$ & 73 & $\begin{array}{c}89,0 \\
2\end{array}$ & 0 & 0,00 \\
\hline \multirow{3}{*}{$\begin{array}{c}\text { Berp } \\
\text { ikir } \\
\text { stati } \\
\text { stik } \\
\text { (stati } \\
\text { stical } \\
\text { think } \\
\text { ing) }\end{array}$} & $\begin{array}{c}\text { Ting } \\
\text { gi }\end{array}$ & 0 & 0,00 & 63 & $\begin{array}{c}76,8 \\
3\end{array}$ \\
\hline & $\begin{array}{c}\text { Seda } \\
\text { ng }\end{array}$ & 5 & 6,10 & 19 & $\begin{array}{c}23,1 \\
7 \\
\end{array}$ \\
\hline & $\begin{array}{c}\text { Rend } \\
\text { ah }\end{array}$ & 77 & $\begin{array}{c}93,9 \\
0\end{array}$ & 0 & 0,00 \\
\hline
\end{tabular}


Tabel 4 di atas menggambarkan persentase jumlah mahasiswa yang mempunyai kemampuan melek statistik (statistical literacy) sebelum dan sesudah pembelajaran pada kelas eksperimen. Pada kelas kontrol persentase jumlah mahasiswa yang mempunyai kemampuan melek statistik (statistical literacy) rendah mengalami penurunan setelah dilakukan pembelajaran. Persentase jumlah mahasiswa yang mempunyai kemampuan melek statistik (statistical literacy) sedang mengalami kenaikan setelah dilakukan pembelajaran. Persentase jumlah mahasiswa yang mempunyai kemampuan melek statistik (statistical literacy) tinggi mengalami kenaikan setelah dilakukan pembelajaran.

Tabel 4 di atas menggambarkan persentase jumlah mahasiswa yang mempunyai kemampuan penalaran statistik (statistical reasoning) sebelum dan sesudah pembelajaran pada kelas eksperimen. Pada kelas kontrol persentase jumlah mahasiswa yang mempunyai kemampuan penalaran statistik (statistical reasoning) rendah mengalami penurunan setelah dilakukan pembelajaran. Persentase jumlah mahasiswa yang mempunyai kemampuan penalaran statistik (statistical reasoning) sedang mengalami kenaikan setelah dilakukan pembelajaran. Persentase jumlah mahasiswa yang mempunyai kemampuan penalaran statistik (statistical reasoning) tinggi mengalami kenaikan setelah dilakukan pembelajaran.

Tabel 4 di atas menggambarkan persentase jumlah mahasiswa yang mempunyai kemampuan berpikir statistik (statistical thinking) sebelum dan sesudah pembelajaran pada kelas eksperimen. Pada kelas kontrol persentase jumlah mahasiswa yang mempunyai kemampuan berpikir statistik (statistical thinking) rendah mengalami penurunan setelah dilakukan pembelajaran. Persentase jumlah mahasiswa yang mempunyai kemampuan berpikir statistik (statistical thinking) sedang mengalami kenaikan setelah dilakukan pembelajaran. Persentase jumlah mahasiswa yang mempunyai kemampuan berpikir statistik (statistical thinking) tinggi mengalami kenaikan setelah dilakukan pembelajaran.

\subsection{Peningkatan Kemampuan Statistik}

$\begin{array}{llr}\begin{array}{l}\text { Klasifikasi } \\ \text { kemampuan }\end{array} \text { (gain) } & \text { peningkatan } \\ \text { statistik } \\ \text { dimodifikasi dari } & \text { (Pujiastuti, } & 2019) . \\ \text { Tabel } 5 \text { dan gambar } 3 & \text { berikut }\end{array}$


menggambarkan

peningkatan

kemampuan statistik setiap mahasiswa pada kelas kontrol sebelum dan sesudah pembelajaran.

Tabel 5. Peningkatan Kemampuan Statistik

\begin{tabular}{|c|c|c|c|c|}
\hline \multirow{2}{*}{$\begin{array}{c}\text { Klasifi } \\
\text { kasi } \\
\text { Penin } \\
\text { gkatan } \\
\text { Kema } \\
\text { mpua } \\
\text { n } \\
\text { Statist } \\
\text { ik }\end{array}$} & \multicolumn{2}{|c|}{ Kelas Kontrol } & \multicolumn{2}{|c|}{$\begin{array}{c}\text { Kelas } \\
\text { Eksperimen }\end{array}$} \\
\hline & $\begin{array}{c}\text { Frek } \\
\text { uens } \\
i\end{array}$ & $\begin{array}{l}\text { Prese } \\
\text { ntase }\end{array}$ & $\begin{array}{c}\text { Frek } \\
\text { uens } \\
i\end{array}$ & $\begin{array}{l}\text { Prese } \\
\text { ntase }\end{array}$ \\
\hline Tinggi & 13 & 15,85 & 54 & 65,85 \\
\hline $\begin{array}{c}\text { Sedan } \\
\mathrm{g}\end{array}$ & 39 & 47,56 & 28 & 34,15 \\
\hline $\begin{array}{c}\text { Renda } \\
\mathrm{h}\end{array}$ & 30 & 36,59 & 0 & 0,00 \\
\hline
\end{tabular}

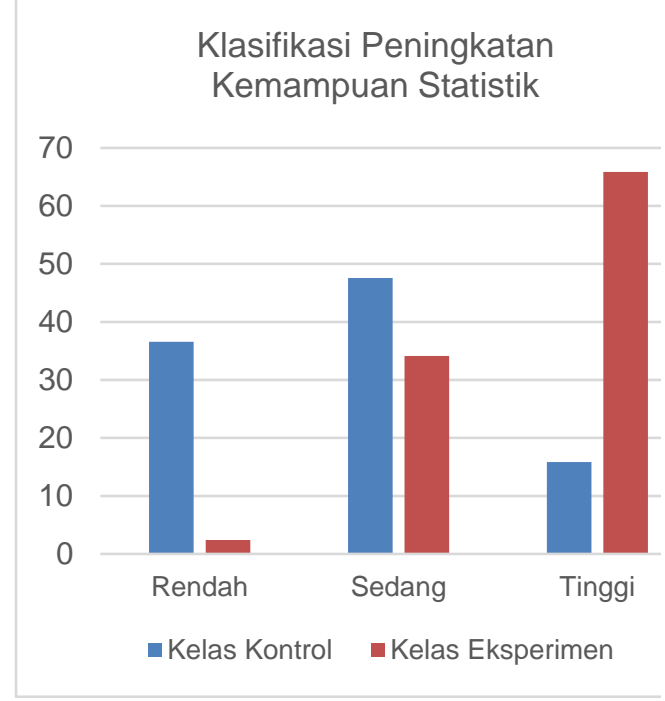

Grafik 3. Peningkatan Kemampuan Statistika

Tabel 5 dan grafik 3 di atas menggambarkan persentase jumlah mahasiswa yang mempunyai peningkatan kemampuan statistik pada kelas kontrol dan kelas eksperimen. Persentase jumlah mahasiswa yang mempunyai peningkatan kemampuan statistik kategori rendah yaitu kelas kontrol lebih besar daripada kelas eksperimen. Persentase jumlah mahasiswa yang mempunyai peningkatan kemampuan statistik kategori sedang yaitu kelas kontrol lebih besar daripada kelas eksperimen. Persentase jumlah mahasiswa yang mempunyai peningkatan kemampuan statistik kategori tinggi yaitu kelas eksperimen lebih besar daripada kelas kontrol.

Berikut ini adalah tabel rincian peningkatan kemampuan statistik setiap mahasiswa pada setiap indikator yaitu melek statistik (statistical literacy), penalaran statistik (statistical reasoning) dan berpikir statistik (statistical thinking) pada kelas kontrol sebelum dan sesudah pembelajaran. 
Tabel 6. Peningkatan Kemampuan

Statistik pada Setiap Indikator Kemampuan

\begin{tabular}{|c|c|c|c|c|c|}
\hline \multirow{2}{*}{$\begin{array}{l}\text { Indik } \\
\text { ator } \\
\text { kem } \\
\text { amp } \\
\text { uan } \\
\text { stati } \\
\text { stik }\end{array}$} & \multirow{2}{*}{$\begin{array}{c}\text { Klas } \\
\text { ifika } \\
\text { si } \\
\text { Peni } \\
\text { ngka } \\
\text { tan }\end{array}$} & \multicolumn{2}{|c|}{$\begin{array}{c}\text { Kelas } \\
\text { Kontrol }\end{array}$} & \multicolumn{2}{|c|}{$\begin{array}{c}\text { Kelas } \\
\text { Eksperime } \\
n\end{array}$} \\
\hline & & $\begin{array}{l}\text { Fre } \\
\text { kue } \\
\text { nsi }\end{array}$ & $\begin{array}{l}\text { Pre } \\
\text { sent } \\
\text { ase }\end{array}$ & $\begin{array}{l}\text { Fre } \\
\text { kue } \\
\text { nsi }\end{array}$ & $\begin{array}{c}\text { Pre } \\
\text { sent } \\
\text { ase }\end{array}$ \\
\hline \multirow{3}{*}{$\begin{array}{c}\text { Mele } \\
\mathrm{k} \\
\text { statis } \\
\text { tik } \\
\text { (stati } \\
\text { stical } \\
\text { litera } \\
\text { cy) }\end{array}$} & $\begin{array}{c}\text { Ting } \\
\text { gi }\end{array}$ & 15 & $\begin{array}{c}18,2 \\
9\end{array}$ & 55 & $\begin{array}{c}67,0 \\
7\end{array}$ \\
\hline & $\begin{array}{c}\text { Seda } \\
\text { ng }\end{array}$ & 46 & $\begin{array}{c}56,1 \\
0\end{array}$ & 27 & $\begin{array}{c}32,9 \\
3\end{array}$ \\
\hline & $\begin{array}{l}\text { Ren } \\
\text { dah }\end{array}$ & 21 & $\begin{array}{c}25,6 \\
1\end{array}$ & 0 & 0,00 \\
\hline \multirow{3}{*}{$\begin{array}{c}\text { Pena } \\
\text { laran } \\
\text { statis } \\
\text { tik } \\
\text { (stati } \\
\text { stical } \\
\text { reas } \\
\text { onin } \\
\text { g) }\end{array}$} & $\begin{array}{c}\text { Ting } \\
\text { gi }\end{array}$ & 13 & $\begin{array}{c}15,8 \\
5 \\
\end{array}$ & 52 & $\begin{array}{c}63,4 \\
1 \\
\end{array}$ \\
\hline & $\begin{array}{c}\text { Seda } \\
\text { ng }\end{array}$ & 44 & $\begin{array}{c}53,6 \\
6\end{array}$ & 30 & $\begin{array}{c}36,5 \\
9\end{array}$ \\
\hline & $\begin{array}{l}\text { Ren } \\
\text { dah }\end{array}$ & 25 & $\begin{array}{c}30,4 \\
9\end{array}$ & 0 & 0,00 \\
\hline \multirow{3}{*}{$\begin{array}{c}\text { Berpi } \\
\text { kir } \\
\text { statis } \\
\text { tik } \\
\text { (stati } \\
\text { stical } \\
\text { thinki } \\
\text { ng) }\end{array}$} & $\begin{array}{c}\text { Ting } \\
\mathrm{gi}\end{array}$ & 11 & $\begin{array}{c}13,4 \\
1\end{array}$ & 55 & $\begin{array}{c}67,0 \\
7\end{array}$ \\
\hline & $\begin{array}{c}\text { Seda } \\
\text { ng }\end{array}$ & 43 & $\begin{array}{c}52,4 \\
4\end{array}$ & 27 & $\begin{array}{c}32,9 \\
3\end{array}$ \\
\hline & $\begin{array}{l}\text { Ren } \\
\text { dah }\end{array}$ & 28 & $\begin{array}{c}34,1 \\
5\end{array}$ & 0 & 0,00 \\
\hline
\end{tabular}

Tabel 6 di atas menggambarkan persentase jumlah mahasiswa yang mempunyai peningkatan kemampuan melek statistik (statistical literacy) pada kelas kontrol dan kelas eksperimen. Persentase jumlah mahasiswa yang mempunyai peningkatan kemampuan melek statistik (statistical literacy) kategori 112 rendah yaitu kelas kontrol lebih besar daripada kelas eksperimen. Persentase jumlah mahasiswa yang mempunyai peningkatan kemampuan melek statistik (statistical literacy) kategori sedang yaitu kelas kontrol lebih besar daripada kelas eksperimen. Persentase jumlah mahasiswa yang mempunyai peningkatan kemampuan melek statistik (statistical literacy) kategori tinggi yaitu kelas eksperimen lebih besar daripada kelas kontrol.

Tabel 6 di atas menggambarkan persentase jumlah mahasiswa yang mempunyai peningkatan kemampuan penalaran statistik (statistical reasoning) pada kelas kontrol dan kelas eksperimen. Persentase jumlah mahasiswa yang mempunyai peningkatan kemampuan penalaran statistik (statistical reasoning) kategori rendah yaitu kelas kontrol lebih besar daripada kelas eksperimen. Persentase jumlah mahasiswa yang mempunyai peningkatan kemampuan penalaran statistik (statistical reasoning) kategori sedang yaitu kelas kontrol lebih besar daripada kelas eksperimen. Persentase jumlah mahasiswa yang mempunyai peningkatan kemampuan penalaran statistik (statistical reasoning) kategori tinggi yaitu kelas eksperimen lebih besar daripada kelas kontrol. 
Tabel 6 di atas menggambarkan persentase jumlah mahasiswa yang mempunyai peningkatan kemampuan berpikir statistik (statistical thinking) pada kelas kontrol dan kelas eksperimen. Persentase jumlah mahasiswa yang mempunyai peningkatan kemampuan berpikir statistik (statistical thinking) kategori rendah yaitu kelas kontrol lebih besar daripada kelas eksperimen. Persentase jumlah mahasiswa yang mempunyai peningkatan kemampuan berpikir statistik (statistical thinking) kategori sedang yaitu kelas kontrol lebih besar daripada kelas eksperimen. Persentase jumlah mahasiswa yang mempunyai peningkatan kemampuan berpikir statistik (statistical thinking) kategori tinggi yaitu kelas eksperimen lebih besar daripada kelas kontrol.

\subsection{Self-Confidence}

\subsubsection{Self-Confidence Kelas Kontrol}

Berikut ini adalah tabel selfconfidence setiap mahasiswa pada kelas kontrol sebelum dan sesudah pembelajaran.

Tabel 7. Kemampuan Self-confidence

\begin{tabular}{|c|c|c|c|c|}
\hline \multirow{2}{*}{$\begin{array}{l}\text { Kriteri } \\
\text { a Self- } \\
\text { Confi } \\
\text { dence }\end{array}$} & \multicolumn{2}{|c|}{ Sebelum } & \multicolumn{2}{|c|}{ Sesudah } \\
\hline & $\begin{array}{c}\text { Frek } \\
\text { uensi }\end{array}$ & $\begin{array}{l}\text { Prese } \\
\text { ntase }\end{array}$ & $\begin{array}{l}\text { Frek } \\
\text { uens } \\
\text { i }\end{array}$ & $\begin{array}{l}\text { Prese } \\
\text { ntase }\end{array}$ \\
\hline
\end{tabular}

\begin{tabular}{|c|c|c|c|c|}
\hline $\begin{array}{c}\text { Sanga } \\
\text { t Baik }\end{array}$ & 1 & 1,22 & 1 & 1,22 \\
\hline Baik & 40 & 48,78 & 43 & 52,44 \\
\hline Cukup & 33 & 40,24 & 33 & 40,24 \\
\hline $\begin{array}{c}\text { Kuran } \\
\mathrm{g}\end{array}$ & 8 & 9,76 & 5 & 6,10 \\
\hline $\begin{array}{c}\text { Sanga } \\
\mathrm{t} \\
\text { Kuran } \\
\mathrm{g}\end{array}$ & 0 & 0,00 & 0 & 0,00 \\
\hline
\end{tabular}

\section{Self-Confidence Kelas Kontrol}

60

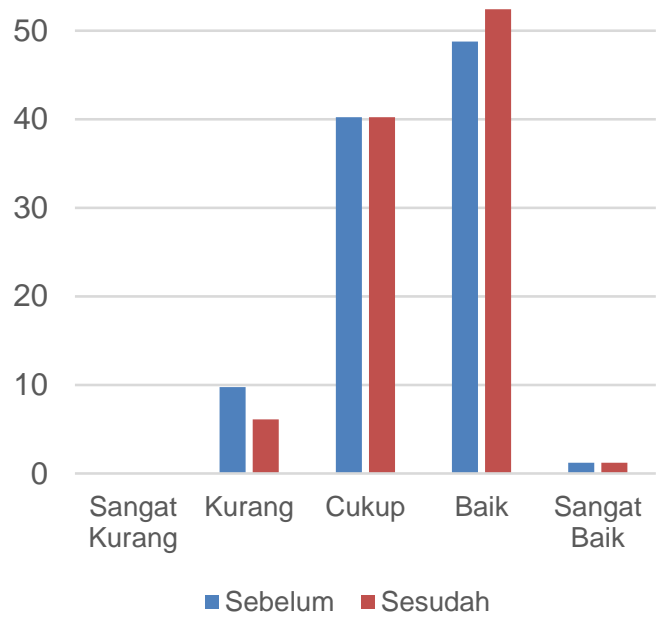

Grafik 4. Kemampuan Self-Confidene

Tabel 7 dan 4 grafik di atas menggambarkan presentase jumlah mahasiswa yang mempunyai selfconfidence dengan kriteria selfconfidence sangat baik, selfconfidence baik, self-confidence cukup, self-confidence kurang dan 
self-confidence sangat kurang pada kelas kontrol setelah dilakukan pembelajaran. Pada kelas kontrol persentase jumlah mahasiswa yang mempunyai self-confidence kurang mengalami penurunan setelah dilakukan pembelajaran. Pada kelas kontrol persentase jumlah mahasiswa yang mempunyai self-confidence baik mengalami kenaikan setelah dilakukan pembelajaran. Sedangkan presentase jumlah mahasiswa yang mempunyai self-confidence sangat kurang, cukup dan sangat baik, tidak mengalami perubahan kenaikan maupun penurunan.

\subsubsection{Self-confidence Kelas Eksperimen}

Berikut ini adalah tabel dan grafik self-confidence setiap mahasiswa pada kelas eksperimen sebelum dan sesudah pembelajaran.

Tabel 8. Kemampuan Self-confidence

\begin{tabular}{|c|c|c|c|c|}
\hline Kriteri & \multicolumn{2}{|c|}{ Sebelum } & \multicolumn{2}{c|}{ Sesudah } \\
\cline { 2 - 5 } $\begin{array}{c}\text { Self- } \\
\text { Confi } \\
\text { dence }\end{array}$ & $\begin{array}{c}\text { Frek } \\
\text { uensi }\end{array}$ & $\begin{array}{c}\text { Prese } \\
\text { ntase }\end{array}$ & $\begin{array}{c}\text { Frek } \\
\text { uens } \\
\mathbf{i}\end{array}$ & $\begin{array}{c}\text { Prese } \\
\text { ntase }\end{array}$ \\
\hline $\begin{array}{c}\text { Sanga } \\
\text { t Baik }\end{array}$ & 0 & 0,00 & 16 & 19,51 \\
\hline Baik & 40 & 48,78 & 55 & 67,07 \\
\hline Cukup & 32 & 39,02 & 11 & 13,41 \\
\hline $\begin{array}{c}\text { Kuran } \\
\text { g }\end{array}$ & 10 & 12,20 & 0 & 0,00 \\
\hline $\begin{array}{c}\text { Sanga } \\
\text { t }\end{array}$ & 0 & 0,00 & 0 & 0,00 \\
\hline
\end{tabular}

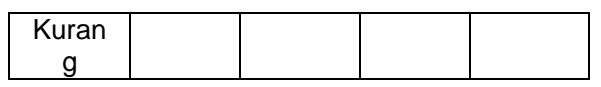

Self-Confidence Kelas Ekperimen

80

70

60

50

40

30

20

10

0

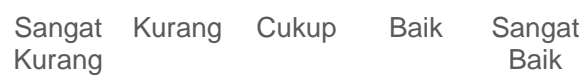

ロ Sebelum -Sesudah

Grafik 5. Kemampuan Self-

Confidence

Tabel 8 dan Grafik 5 di atas menggambarkan presentase jumlah mahasiswa yang mempunyai selfconfidence dengan kriteria selfconfidence sangat baik, selfconfidence baik, self-confidence cukup, self-confidence kurang dan self-confidence sangat kurang pada kelas eksperimen setelah dilakukan pembelajaran. Pada kelas eksperimen 
persentase jumlah mahasiswa yang mempunyai self-confidence kurang mengalami penurunan setelah dilakukan pembelajaran. Pada kelas eksperimen persentase jumlah mahasiswa yang mempunyai selfconfidence cukup mengalami penurunan setelah dilakukan pembelajaran. Pada kelas kontrol persentase jumlah mahasiswa yang mempunyai self-confidence baik mengalami kenaikan setelah dilakukan pembelajaran. Pada kelas kontrol persentase jumlah mahasiswa yang mempunyai self-confidence sangat baik mengalami kenaikan setelah dilakukan pembelajaran. Sedangkan presentase jumlah mahasiswa yang mempunyai selfconfidence sangat kurang, tidak mengalami perubahan kenaikan maupun penurunan.

\section{Hasil Analisis Statistika Inferensial}

\subsection{Uji Asumsi Statistik}

\subsubsection{Uji Normalitas Data}

Berikut ini adalah hasil uji normalitas data peningkatan kemampuan statistika pada kelas control dan kelas eksperimen untuk menentukan uji hipotesis yang akan digunakan pada hipotesis 1 .
Tabel 9. Normalitas Data Hipotesis 1

\begin{tabular}{l|r|r|r} 
& \multicolumn{3}{|c}{ Shapiro-Wilk } \\
& Statistic & \multicolumn{1}{c}{ df } & \multicolumn{1}{c}{ Sig. } \\
\hline $\begin{array}{l}\text { Gain Kemampuan Statistika } \\
\text { pada Kelas Kontrol }\end{array}$ & .978 & 82 & .182 \\
\hline $\begin{array}{l}\text { Gain Kemampuan Statistika } \\
\text { pada Kelas Eksperimen }\end{array}$ & .934 & 82 & .000 \\
\hline
\end{tabular}

Berdasarkan tabel 9 di atas, nilai Sig. data peningkatan kemampuan statistika pada kelas kontrol adalah 0,182 lebih besar dari 0,05 menggunakan uji Shapiro-Wilk, maka data tersebut berdistribusi normal. Berdasarkan tabel di atas nilai Sig. data peningkatan kemampuan statistika pada kelas eksperimen adalah 0,000 kurang dari 0,05 menggunakan uji Shapiro-Wilk, maka data tersebut berdistribusi tidak normal.

Berikut ini adalah hasil uji normalitas data peningkatan kemampuan melek statistis (statistical literacy) pada kelas kontrol dan kelas eksperimen untuk menentukan uji hipotesis yang akan digunakan pada hipotesis 2.

Tabel 10. Normalitas Data Hipotesis 2 


\begin{tabular}{|c|c|c|c|}
\hline & \multicolumn{3}{|c|}{ Shapiro-Willk } \\
\hline & Statistic & $\mathrm{df}$ & Sig \\
\hline $\begin{array}{l}\text { Gain Statistical Literacy pada } \\
\text { Kelas Kontrol }\end{array}$ & .976 & 82 & \\
\hline $\begin{array}{l}\text { Gain Statistical Literacy pada } \\
\text { Kelas Eksperimen }\end{array}$ & .965 & 82 & \\
\hline
\end{tabular}

Berdasarkan 10 tabel di atas, nilai Sig. data peningkatan kemampuan melek statistis (statistical literacy) pada kelas kontrol adalah 0,124 lebih besar dari 0,05 menggunakan uji Shapiro-Wilk, maka data tersebut berdistribusi normal. Berdasarkan tabel di atas nilai Sig. data peningkatan kemampuan melek statistis (statistical literacy) pada kelas eksperimen adalah 0,024 kurang dari 0,05 menggunakan uji Shapiro-Wilk, maka data tersebut berdistribusi tidak normal.

Berikut ini adalah hasil uji normalitas data peningkatan kemampuan penalaran statistis (statistical reasoning) pada kelas kontrol dan kelas eksperimen untuk menentukan uji hipotesis yang akan digunakan pada hipotesis 3 .

Tabel 11. Normalitas Data Hipotesis 3

\begin{tabular}{l|r|r|r} 
& \multicolumn{3}{|c}{ Shapiro-Wilk } \\
& Statistic & \multicolumn{1}{c}{ df } & \multicolumn{1}{c}{ Sig. } \\
\hline $\begin{array}{l}\text { Gain Statistical Reasonig } \\
\text { pada Kelas Kontrol }\end{array}$ & .962 & 82 & .017 \\
\hline $\begin{array}{l}\text { Gain Statistical Reasonig } \\
\text { pada Kelas Eksperimen }\end{array}$ & .959 & 82 & .010 \\
\hline
\end{tabular}

Berdasarkan tabel 11 di atas, nilai Sig. data peningkatan kemampuan penalaran statistis (statistical reasoning) pada kelas kontrol adalah 0,017 lebih kecil dari 0,05 menggunakan uji Shapiro-Wilk, maka data tersebut berdistribusi tidak normal. Berdasarkan tabel di atas nilai Sig. data peningkatan kemampuan penalaran statistis (statistical reasoning) pada kelas eksperimen adalah 0,010 kurang dari 0,05 menggunakan uji Shapiro-Wilk, maka data tersebut berdistribusi tidak normal.

Berikut ini adalah hasil uji normalitas data peningkatan kemampuan berpikir statistis (statistical thinking) pada kelas kontrol dan kelas eksperimen untuk menentukan uji hipotesis yang akan digunakan pada hipotesis 4 .

Tabel 12. Normalitas Data Hipotesis 4 


\begin{tabular}{l|r|r|r} 
& \multicolumn{3}{|c}{ Shapiro-Wilk } \\
& Statistic & df & Si \\
\hline $\begin{array}{l}\text { Gain Statistical Thinking } \\
\text { pada Kelas Kontrol }\end{array}$ & .964 & 82 & \\
$\begin{array}{l}\text { Gain Statistical Thinking } \\
\text { pada Kelas Eksperimen }\end{array}$ & .934 & 82 & \\
\hline
\end{tabular}

Berdasarkan tabel 12 di atas, nilai Sig. data peningkatan kemampuan berpikir statistis (statistical thinking) pada kelas kontrol adalah 0,022 lebih kecil dari 0,05 menggunakan uji Shapiro-Wilk, maka data tersebut berdistribusi tidak normal. Berdasarkan tabel di atas nilai Sig. data peningkatan kemampuan berpikir statistis (statistical thinking) pada kelas eksperimen adalah 0,000 kurang dari 0,05 menggunakan uji ShapiroWilk, maka data tersebut berdistribusi tidak normal.

Berikut ini adalah hasil uji normalitas data self-confidence sebelum dan sesudah pembelajaran pada kelas kontrol untuk menentukan uji hipotesis yang akan digunakan pada hipotesis 5 .

Tabel 13. Normalitas Data Hipotesis 5

\begin{tabular}{lr|r|r|r} 
& & \multicolumn{3}{|c}{ Shapiro-Wilk } \\
& \multicolumn{1}{c}{ Statistic } & \multicolumn{1}{c}{ df } & Sir \\
\hline $\begin{array}{l}\text { Kelas } \quad \text { Kontrol } \\
\text { Confidence Pre-Test }\end{array}$ & Self & .946 & 82 & \\
\hline $\begin{array}{l}\text { Kelas Kontrol } \\
\text { Confidence Post-Test }\end{array}$ & Self & .919 & 82 & \\
\hline
\end{tabular}

Berdasarkan tabel 13 di atas, nilai Sig. data self-confidence sebelum pembelajaran pada kelas kontrol adalah 0,002 lebih kecil dari 0,05 menggunakan uji Shapiro-Wilk, maka data tersebut berdistribusi tidak normal. Berdasarkan tabel di atas nilai Sig. data self-confidence setelah pembelajaran pada kelas kontrol adalah 0,000 kurang dari 0,05 menggunakan uji Shapiro-Wilk, maka data tersebut berdistribusi tidak normal.

Berikut ini adalah hasil uji normalitas data self-confidence sebelum dan sesudah pembelajaran pada kelas eksperimen untuk menentukan uji hipotesis yang akan digunakan yang akan digunakan pada hipotesis 6 .

Tabel 14. Normalitas Data Hipotesis 6

\begin{tabular}{|c|c|c|c|}
\hline & \multicolumn{3}{|c|}{ Shapiro-Wilk } \\
\hline & Statistic & df & Sig. \\
\hline $\begin{array}{lr}\text { Kelas Eksperimen } & \text { Self } \\
\text { Confidence } & \text { Pre-Test } \\
\text { menggunakan } & \text { Hippo } \\
\text { Animator } & \\
\end{array}$ & .944 & 82 & .001 \\
\hline $\begin{array}{lr}\text { Kelas Eksperimen } & \text { Self } \\
\text { Confidence } & \text { Post-Test } \\
\text { menggunakan } & \text { Hippo } \\
\text { Animator } & \end{array}$ & .970 & 82 & .056 \\
\hline
\end{tabular}

Berdasarkan tabel 14 di atas, nilai Sig. data self-confidence sebelum pembelajaran pada kelas kontrol adalah 0,001 lebih kecil dari 0,05 
menggunakan uji Shapiro-Wilk, maka data tersebut berdistribusi tidak normal. Berdasarkan tabel di atas nilai Sig. data self-confidence setelah pembelajaran pada kelas eksperimen adalah 0,056 lebih besar dari 0,05 menggunakan uji Shapiro-Wilk, maka data tersebut berdistribusi normal.

\subsubsection{Uji Homogenitas Data}

Berikut ini adalah hasil uji homogenitas data untuk setiap uji hipotesis yang diajukan untuk taraf signifikan 0,05 menggunakan $\mathrm{Uji}$ Levene berbasis rata-rata.

Tabel 15. Uji Levene

\begin{tabular}{|c|l|l|l|}
\hline Hipotesis & $\begin{array}{l}\text { Levene } \\
\text { Statistic }\end{array}$ & Sig. & Homogen \\
\hline 1 & 56,687 & 0,000 & Tidak \\
\hline 2 & 28,880 & 0,000 & Tidak \\
\hline 3 & 31.419 & 0,000 & Tidak \\
\hline 4 & 55.386 & 0,000 & Tidak \\
\hline 5 & 0,265 & 0,608 & Iya \\
\hline 6 & 6,262 & 0,013 & Tidak \\
\hline
\end{tabular}

Berdasarkan uji Levene pada tabel di atas, Data untuk uji hipotesis 1, 2, 3, 4 dan 6 bervariansi tidak homogen. Data untuk uji hipotesis 5 bervariansi homogen.

\subsection{Uji Hipotesis}

Pemilihan jenis uji pada uji hipotesis berdasarkan hasil uji asumsi statistik yang sudah dilakukan di atas. Tabel berikut ini adalah tabel rangkuman hasil uji asumsi statistik dan keputusan jenis uji hipotesis yang akan dilakukan untuk menentukan $\mathrm{H} 0$ atau $\mathrm{H} 1$ yang diteima.

Tabel 16. Keputusan Uji Statistik

\begin{tabular}{|c|c|c|c|}
\hline $\begin{array}{l}\text { Hipote } \\
\text { sis }\end{array}$ & $\begin{array}{l}\text { Normalit } \\
\text { as }\end{array}$ & $\begin{array}{c}\text { Homog } \\
\text { en }\end{array}$ & $\begin{array}{c}\text { Uji } \\
\text { Statistik }\end{array}$ \\
\hline 1 & $\begin{array}{c}\text { Kedua } \\
\text { data } \\
\text { berdistrib } \\
\text { usi tidak } \\
\text { normal }\end{array}$ & Tidak & $\begin{array}{c}\text { Non } \\
\text { paramet } \\
\text { rik: } \\
\text { Mann- } \\
\text { Whitney } \\
\text { U }\end{array}$ \\
\hline 2 & $\begin{array}{c}\text { Kedua } \\
\text { data } \\
\text { berdistrib } \\
\text { usi tidak } \\
\text { normal }\end{array}$ & Tidak & $\begin{array}{c}\text { Non } \\
\text { paramet } \\
\text { rik: } \\
\text { Mann- } \\
\text { Whitney } \\
\text { U }\end{array}$ \\
\hline 3 & $\begin{array}{c}\text { Kedua } \\
\text { data } \\
\text { berdistrib } \\
\text { usi tidak } \\
\text { normal }\end{array}$ & Tidak & $\begin{array}{c}\text { Non } \\
\text { paramet } \\
\text { rik: } \\
\text { Mann- } \\
\text { Whitney } \\
\text { U }\end{array}$ \\
\hline 4 & $\begin{array}{c}\text { Kedua } \\
\text { data } \\
\text { berdistrib } \\
\text { usi tidak } \\
\text { normal }\end{array}$ & Tidak & $\begin{array}{c}\text { Non } \\
\text { paramet } \\
\text { rik: } \\
\text { Mann- } \\
\text { Whitney } \\
\text { U }\end{array}$ \\
\hline 5 & $\begin{array}{c}\text { Kedua } \\
\text { data } \\
\text { berdistrib } \\
\text { usi tidak } \\
\text { normal }\end{array}$ & Iya & $\begin{array}{c}\text { Non } \\
\text { paramet } \\
\text { rik: } \\
\text { Mann- } \\
\text { Whitney } \\
\text { U }\end{array}$ \\
\hline 6 & $\begin{array}{c}\text { Satu } \\
\text { data } \\
\text { berdistrib } \\
\text { usi tidak } \\
\text { normal } \\
\text { dan satu } \\
\text { data } \\
\text { berdistrib }\end{array}$ & Tidak & $\begin{array}{c}\text { Non } \\
\text { paramet } \\
\text { rik: } \\
\text { Mann- } \\
\text { Whitney } \\
\text { U }\end{array}$ \\
\hline
\end{tabular}




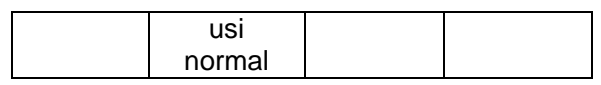

\subsubsection{Hasil Uji Mann-Whitney U Hipotesis 1}

Berdasarkan tabel output SPSS HO ditolak, sehingga diketahui terdapat perbedaan yang signifikan peningkatan kemampuan statistik kelas kontrol dan kelas eksperimen yang melakukan pembelajaran menggunakan hippo animasi di era pandemi covid 19. Dilihat dari nilai mean dan median data, hipotesis ini bermakna bahwa kelas eksperimen yang menggunakan hippo animator memiliki peningkatan kemampuan statistik lebih tinggi secara daripada kelas kontrol yang pembelajaran online dengan zoom dan google meet.

\subsubsection{Hasil Uji Mann-Whitney U Hipotesis 2}

Berdasarkan tabel output SPSS di atas $\mathrm{HO}$ ditolak, sehingga diketahui terdapat perbedaan yang signifikan peningkatan kemampuan melek statistik (statistical literacy) kelas kontrol dan kelas eksperimen yang melakukan pembelajaran menggunakan hippo animasi di era pandemi covid 19. Dilihat dari nilai mean dan median data, hipotesis ini bermakna kelas eksperimen yang menggunakan hippo animator memiliki peningkatan kemampuan melek statistik (statistical literacy) tinggi daripada kelas kontrol yang pembelajaran online dengan zoom dan google meet.

\subsubsection{Hasil Uji Mann-Whitney U Hipotesis 3}

Berdasarkan tabel output SPSS di atas $\mathrm{HO}$ ditolak, sehingga diketahui terdapat perbedaan yang signifikan peningkatan kemampuan penalaran statistik (statistical reasoning) kelas kontrol dan kelas eksperimen yang melakukan pembelajaran menggunakan hippo animasi di era pandemi covid 19. Dilihat dari nilai mean dan median data, hipotesis ini bermakna kelas eksperimen yang menggunakan hippo animator memiliki peningkatan kemampuan penalaran statistik (statistical reasoning) tinggi secara daripada kelas kontrol yang pembelajaran online dengan zoom dan google meet.

\subsubsection{Hasil Uji Mann-Whitney U Hipotesis 4}

Berdasarkan tabel output SPSS di atas $\mathrm{HO}$ ditolak, sehingga diketahui terdapat perbedaan yang signifikan peningkatan kemampuan berpikir statistik (statistical thinking) kelas kontrol dan kelas eksperimen yang melakukan

pembelajaran 
menggunakan hippo animasi di era pandemi covid 19. Dilihat dari nilai mean dan median data, hipotesis ini bermakna kelas eksperimen yang menggunakan hippo animator memiliki peningkatan kemampuan berpikir statistis (statistical thinking) tinggi secara daripada kelas kontrol yang pembelajaran online dengan zoom dan google meet.

\subsubsection{Hasil Uji Mann-Whitney U Hipotesis 5}

Berdasarkan tabel output SPSS di atas $\mathrm{HO}$ diterima, sehingga diketahui tidak ada peningkatan yang signifikan self-confidence kelas kontrol yang melakukan pembelajaran online tanpa menggunakan hippo animasi di era pandemi covid 19.

\subsubsection{Hasil Uji Mann-Whitney U Hipotesis 6}

Berdasarkan tabel output SPSS di atas $\mathrm{HO}$ ditolak, sehingga diketahui terdapat peningkatan yang signifikan self-confidence kelas eksperimen yang melakukan pembelajaran menggunakan hippo animasi di era pandemi covid 19.

\section{PEMBAHASAN}

Sebagaian besar mahasiswa di perguruan tinggi Indonesia beranggapan bahwa mata kuliah yang menjadi momok bagi mahasiswa (Ulpah, 2009). Ini merupakan tantang bagi pendidik agar dapt memnberikan solusi pembelajran yang efektif dan efisien untuk mengurangi stigma terhadap mata kuliah statistika. Penerapan hippo aminator pada penelitian ini memberikan warna berbeda dalam pembelajaran statistika. Penelitian (Widjayanti et al., 2018), menemukan bahwa media pembelajaran interaktif berbasis animasi adalah efektif dan efisien. Sejalan dengan penelitian tersebut, pada penelitian ini diketahui bahwa pembelajaran menggunakan hippo animator dapat meningkatkan kemampuan statistika mahasiswa secara siginfikan. Hal ini membuktikan bahwa pembelajaran berbasis komputer (animasi) memberikan pengaruh terhadap kemampuan peserta didik. Selain itu, pada penelitian ini dilakukan pengkajian secara mendalam terhadap peningkatan unsur-unsur yang ada di dalam kemampuan statistika, yaitu melek statistik (statistical literacy), penalaran statistis (statistical reasoning) dan berpikir statistis (statistical thinking).

Melek statistik (statistical literacy) bagian dari kemampuan statistik yang penting bagi peserta didik sebagai penyaji dan atau pembaca data 
(Hafiyusholeh, 2015). Pada penelitian ini penggunaan hippo dapat meningkatkan kemampuan melek statistik (statistical literacy) secara signfifikan. Hasil ini sejalan dengan penelitian didik (M. P. Wulandari, 2019) bahwa media pembelajaran interaktif animasi mempunyai efektifitas dalam upaya meningkatkan kemampuan literasi peserta didik.

Penalaran statistik (statistical reasoning) bagian dari kemampuan statistik yang penting bagi peserta didik dalam melakukan penalaran berhubungan dengan angka yang bersifat probabilitas (Sariningsih \& Herdiman, 2017). Penelitian (La Nani et al., 2020) menemukan bahwa kemampuan penalaran statistik (statistical reasoning) dapat ditingkatkan melalui pembelajaran berbasis ICT. Penelitian (Umbara et al., 2020) menemukan bahwa hippo animator efektif untuk mengembagkan kemampuan penalaran (reasoning abilities). Penelitian tersebut sejalan dengan penelitian ini yaitu penggunaan hippo animasi di era pandemi covid 19 dapat meingkatkan kemampuan penalaran statistis (statistical reasoning).

Berpikir statistik (statistical thinking) bagian dari kemampuan statistik yang penting bagi peserta didik dalam melakukan investigasi dalam sebuah penelitian, mulai dari proses pengumpulan data, melakukan pemilihan analisis yang akan digunakan dalam uji asumsi sampai dengan memahami proses penarikan sebuah kesimpulan (Susilawati et al., 2019). Berpikir statistik (statistical thinking) mempunyai ruang lingkup terhadap pendeskripsian data, menyusun data, mereduksi data, merepresentasi data, menganalisis dan mengambil kesimpulan (Masjudin et al., 2020). Pada penelitian ini, penggunaan hippo animasi di era pandemi covid 19 dapat meningkatkan kemampuan berpikir statistik (statistical thinking). Penelitian ini sejalan dengan (La Nani \& Alhaddad, 2020) bahwasanya pembelajaran statistika berbasis ICT mempunyai potensi untuk mendorong peningkatan kemampuan berpikir terkait dengan ide-ide statistik. Secara umum, media animasi komputer dapat mendorong peningkatan kemampuan berpikir (A. Y. R. Wulandari, 2017).

Kemampuan self-confidence merupakan aset berharga bagi pembelajar dalam melakukan proses pendidikan untuk mencapai hasil yang diinginkan. Manfaat dari praktik pendidikan dan teori motivasi yaitu meningkatkan tentang pemahaman tentang bagaimana self-confidence peserta didik (Sheldrake, 2016). Self- 
confidence merupakan salah satu faktor psikologis yang paling penting dan merupakan subjek dari banyak penelitian tentang prestasi peserta didik, (Hosein \& Harle, 2018; Waini et al., 2014). Salah satu bagian dari kunci penting supaya sukses akademik yaitu self-confidence dan kunci utama dalam kepercayaan diri adalah persiapan (Budin, 2017). Selfconfidence penting untuk diteliti dan ditingkatkan agar dapat mendukung peningkatan hasil belajar (Andayani \& Amir, 2019). Penelitian (Das, 2019) menyatakan bahwa pembelajaran menggunakan ICT mempunyai peran yang penting dalam mengembangkan self-confidence. Aminasi juga memberikan efek untuk membangun self-confidence pembelajar (Azzajjad et al., 2021). Pada penelitian ini ditemukan bahwa terdapat peningkatan yang signifikan selfconfidence setelah melakukan pembelajaran menggunakan hippo animasi. Sejalan dengan penelitian (Yaniawati et al., 2020), e-learning media berbasis animator memberikan dampak positif terhadap peingkatan self-confidence siswa. Secara umum, media animasi komputer dapat mendorong peningkatan kemampuan berpikir self-confidence siswa.

\section{PENUTUP}

\section{Simpulan}

Peningkatan kemampuan statistik kelas eksperimen yang melakukan pembelajaran menggunakan hippo animasi lebih tinggi secara signifkan dibandingkan kelas kontrol di era pandemi covid 19. Peningkatan kemampuan melek statistic (statistical literacy) kelas eksperimen yang melakukan pembelajaran menggunakan hippo animasi lebih tinggi secara signifkan dibandingkan kelas kontrol di era pandemi covid 19. Peningkatan kemampuan penalaran statistik (statistical reasoning) kelas eksperimen yang melakukan pembelajaran menggunakan hippo animasi lebih tinggi secara signifkan dibandingkan kelas kontrol di era pandemi covid 19. Peningkatan kemampuan berfikir statistik (statistical thinking) kelas eksperimen yang melakukan pembelajaran menggunakan hippo animasi lebih tinggi secara signifkan dibandingkan kelas kontrol di era pandemi covid 19. Tidak terdapat peningkatan yang signifikan self-confidence kelas kontrol yang melakukan pembelajaran online tanpa menggunakan hippo animasi di era pandemi covid 19. Ada peningkatan yang signifikan selfconfidence kelas eksperimen yang melakukan pembelajaran menggunakan hippo animasi di era 
pandemi covid 19. Secara umum, penerapan Hippo Aminator pada penelitian ini memberikan warna berbeda dalam proses pembelajaran statistika.

\section{DAFTAR PUSTAKA}

Amanullah, M. A. (2020). Pengembangan Media Pembelajaran Flipbook Digital Guna Menunjang Proses Pembelajaran Di Era Revolusi Industri 4.0. Jurnal Dimensi Pendidikan Dan Pembelajaran, 8(1), 37-44.

Andayani, M., \& Amir, Z. (2019). Membangun self-confidence siswa melalui pembelajaran matematika. Desimal: Jurnal Matematika, 2(2), 147-153.

Azzajjad, M. F., Tendrita, M., \& Ahmar, D. S. (2021). Effect of animation and review video making (arvima) in non-classical learning model on independent learning and students' learning outcome. Linguistics and Culture Review, 5(S3), 967-976.

Budin, W. C. (2017). Building Confidence. The Journal of Perinatal Education, 26(3), 197109.

Das, K. (2019). The role and impact of ICT in improving the quality of education: An overview.
International Journal of Innovative Studies in Sociology and Humanities, 4(6), 97-103.

Dennis, M. J. (2020). The impact of COVID-19 on the world economy and higher education. Enrollment Management Report, 24(9), 3.

Ghufron, N., \& Risnawita, R. (2011). Teori-teori Psikologi. Ar-Ruzz Media.

Hafiyusholeh, M. (2015). Literasi statistik dan urgensinya bagi siswa. Wahana: Tridarma Perguruan Tinggi, 64(1), 1-8.

Hidayat, A., \& Perdana, F. J. (2019). Pengaruh Self-Efficacy dan SelfEsteem Terhadap Prestasi Belajar Mahasiswa Pada Sekolah Tinggi IImu Kesehatan Cirebon. Syntax Literate; Jurnal IImiah Indonesia, 4(12), 1-16.

Hollis, P. J. (2011). Ideas for improving statistics education. International Journal of Mathematical Education in Science and Technology, 28(4), 569-573.

Hosein, A., \& Harle, J. (2018). The relationship between students' prior mathematical attainment, knowledge and confidence on their self-assessment accuracy. Studies in Educational Evaluation, 56, 3241.

Kurniawati, U., \& Koeswanti, H. D. (2021). Pengembangan Media 
Pembelajaran Kodig Untuk Meningkatkan Prestasi Belajar Siswa di Sekolah Dasar. Jurnal Basicedu, 5(2), 1046-1052.

La Nani, K., \& Alhaddad, I. (2020). Efektivitas Pembelajaran Berbasis Proyek Berbantuan ICT dalam Peningkatan Kemampuan Komunikasi Statistis Siswa SMP Negeri 2 Kota Ternate pada Materi Statistika. Delta-Pi: Jurnal Matematika Dan Pendidikan Matematika, 9(2).

La Nani, K., Bakar, M. T., \& Saidi, S. (2020). Peningkatan Kemampuan Penalaran Statistis Mahasiswa Melalui Pembelajaran Berbasis Proyek Berbantuan ICT. EDUKASI, 18(2).

Martadiputra, B. A. P. (2010). Kajian Tentang Kemampuan Melek Statistis (statistical Literacy), Penalaran Statistis (statistical Reasoning), Dan Berpikir Statistis (statistical Thinking) Guru Smp. Saung-Guru, 83.

Masjudin, M., Muzaki, A., Abidin, Z., \& Ariyanti, I. A. P. (2020). Analysis of student's statistical thinking ability in understanding the statistical data. Journal of Physics: Conference Series, 1521(3), 32063.

Maskur, R., Nofrizal, N., \& Syazali, M. (2017). Pengembangan Media Pembelajaran Matematika dengan Macromedia Flash. Al-Jabar:
Jurnal Pendidikan Matematika, 8(2), 177-186.

Nazliati, Sari, R., \& Fitriani. (2019). Diagnosis Kecemasan Statistik Pendidikan Pada Mahasiswa NonMatematika FTIK IAIN Langsa. Jurnal Dedikasi Pendidikan, 3(1), 61-75.

Puadi, E. F. (2020). Analisis Sikap Siswa terhadap Multimedia Pembelajaran Matematika berbasis ICT dengan Model Computer Assited Insruction (CAI). Hipotenusa Journal of Research Mathematics Education (HJRME), 3(1), 32-43.

Pujiastuti, I. (2019). Pengembangan Metode Personal Selling Presentation pada Pembelajaraan Telaah Kurikulum dan Buku Teks. CAHAYA PENDIDIKAN, 5(2).

Rahmat, R. F., Mursyida, L., Rizal, F., Krismadinata, K., \& Yunus, Y. (2019). Pengembangan media pembelajaran berbasis mobile learning pada mata pelajaran simulasi digital. Jurnal Inovasi Teknologi Pendidikan, 6(2), 116126.

Sahari, N., Judi, H. M., Mohamed, H., Tengku, Wook, \& Tengku, M. (2011). Student's Attitude towards Statistics Course. Procedia Social and Behavioral Sciences, 18, $287-$ 294.

Sariningsih, R., \& Herdiman, I. (2017). Mengembangkan kemampuan 
penalaran statistik dan berpikir kreatif matematis mahasiswa di Kota Cimahi melalui pendekatan open-ended. Jurnal Riset Pendidikan Matematika, 4(2), 239246.

Setiawan, F. T., Suyitno, H., \& Susilo, B. E. (2017). Analysis of mathematical connection ability and mathematical disposition students of 11th grade Vocational High School. Unnes Journal of Mathematics Education, 6(2), 152162.

Sheldrake, R. (2016). Confidence as motivational expressions of interest, utility, and other influences: Exploring underconfidence and over-confidence in science students at secondary school. International Journal of Educational Research, 76, 50-65.

Susilawati, W., Abdullah, R., \& Rosyidah, I. (2019). Peningkatan kemampuan berpikir statistis mahasiswa melalui challengebased learning dengan strategi konflik kognitif. Jurnal Analisa, 5(1), 31-40.

Torres Martín, C., Acal, C., El Homrani, M., \& Mingorance Estrada, Á. C. (2021). Impact on the Virtual Learning Environment Due to COVID-19. In Sustainability (Vol. 13, Issue 2). https://doi.org/10.3390/su1302058 2
Ulpah, M. (2009). Belajar Statistika: Mengapa dan Bagaimana? Jurnal Pemikiran Alternatif Pendidikan, 14(3), 325-435.

Umbara, U., Munir, Susilana, R., \& Puadi, E. F. W. (2020). The application of ICT learning through Hippani: The effects on mathematical reasoning ability. Journal of Physics: Conference Series, 1521(3).

Waini, I., Hamzah, K., Mohd, R. S., Miswan, N. . H., Amira, N. Z., \& Ahmad, A. (2014). Self Confidence in Mathematics A Case Study on Engineering Technology Students in FTK, UteM. International Journal for Innovation Education and Research, 2(11), 10-13.

Widjayanti, W. R., Masfingatin, T., \& Setyansah, R. K. (2018). Media pembelajaran interaktif berbasis animasi pada materi statistika untuk siswa kelas 7 SMP. Jurnal Pendidikan Matematika, 13(1), 101-112.

Wulandari, A. Y. R. (2017). Pembelajaran menggunakan pendekatan konstruktivisme berbantuan media animasi komputer untuk meningkatkan keterampilan berpikir kritis mahasiswa. Prosiding SNPS (Seminar Nasional Pendidikan Sains), 97-103.

Wulandari, M. P. (2019). Keefektifan Penggunaan Media Video Animasi 
IPA SD Berbasis Literasi Sains Terhadap Hasil Belajar Siswa Kelas IV. JURNAL PANCAR (Pendidik Anak Cerdas Dan Pintar), 3(2).

Yaniawati, P., Kariadinata, R., Sari, N., Pramiarsih, E., \& Mariani, M. (2020). Integration of e-learning for mathematics on resource-based learning: Increasing mathematical creative thinking and selfconfidence. International Journal of Emerging Technologies in Learning (IJET), 15(6), 60-78.

\section{UCAPAN TERIMA KASIH}

Penulis mengucapkan terima kasih kepada Direktorat Riset dan Pengabdian Masyarakat (DRPM), Kemenristek-BRIN yang telah mendanai penelitian ini melalui skema hibah PDP tahun 2021. 